Agro-Science Journal of Tropical Agriculture, Food, Environment and Extension Volume 19 Number 3 (July 2020) pp. $51-61$

ISSN 1119-7455

\title{
CLASSIFICATION AND ASSESSMENT OF AGRICULTURAL POTENTIAL OF THE LOWER NIGER FLOODPLAIN SOILS OF ATANI, SOUTHEASTERN NIGERIA
}

\author{
${ }^{1,2}$ Okenmuo F.C., ${ }^{1}$ Anochie C.O., ${ }^{\text {*3}}$ Ukabiala M.E., ${ }^{2}$ Asadu C.L.A., \\ ${ }^{2,4}$ Kefas P.K. and ${ }^{2}$ Akamigbo F.O.R. \\ ${ }^{1}$ Department of Soil Science, Chukwuemeka Odumegwu Ojukwu University, Igbariam, Nigeria \\ ${ }^{2}$ Department of Soil Science, University of Nigeria, Nsukka, Nigeria \\ ${ }^{3}$ College of Agriculture, Ochaja, Kogi State, Nigeria \\ ${ }^{4}$ Department of Agronomy, Taraba State University, Jalingo, Nigeria \\ "Corresponding author's email: successfulmadu@yahoo.com
}

\begin{abstract}
The soils of Atani floodplain in Anambra State of Nigeria contribute significantly to the food production of the State, hence the need to understand their behavior in order to enhance their management and productivity. Profile pits were sited along three physiographic units viz: levee crest, levee slope and flood basin. Soil samples were collected from the profile horizons and subjected to standard laboratory procedures. Characterization of the soils was based on their morphological, physical and chemical properties. Soil classification was carried out using the USDA Soil Taxonomy and correlated with FAO/IUSS World Reference Base. Its agricultural potential was assessed using the fertility capability classification. The soils were deep. Topsoil colour was dominantly blackish black (10YR 3/2). Mottles were pervasive; an indication of impeded drainage conditions. The soils were predominantly fine textured. Soil pH values ranged from 4.8 to 6.2. Exchangeable Calcium was low to moderate (2.6-8.2 $\left.\mathrm{cmol} \mathrm{kg}^{-1}\right)$; Magnesium was moderate to high (1.6-6.8 $\left.\mathrm{cmol} \mathrm{kg}^{-1}\right)$; Sodium was high to very high (1.0-2.5 $\left.\mathrm{cmol} \mathrm{kg}^{-1}\right)$, while potassium was high $\left(1.2-4.2 \mathrm{cmol} \mathrm{kg}^{-1}\right)$. Cation exchange capacity values ranged from 11.6 to $42.6 \mathrm{cmol} \mathrm{kg}^{-1}$. Total nitrogen was very low to low $\left(0.14-1.12 \mathrm{~g} \mathrm{~kg}^{-1}\right)$, while organic carbon was low to moderate $\left(0.4-15.2 \mathrm{~g} \mathrm{~kg}^{-1}\right)$. Available phosphorus was very low to high ranging from 0.93 to $31.71 \mathrm{mg} \mathrm{kg}^{-1}$ while base saturation ranged from 64 to $93 \%$. The soils were classified as Typic Fluvaquents (Typic Fluvisols), Fluvaquentic Endoaquepts (Endostagnic Cambisols) and Fluventic Endoaquepts (Endostagnic Cambisols) according to the USDA and FAO/IUSS. The fertility capability evaluation of the soils revealed that the pedons were Lgn in classification due to limitations in drainage.
\end{abstract}

Key words: alluvium, cambic horizon, Inceptisols, lithologic discontinuity

\section{INTRODUCTION}

The slow pace of agricultural growth and development in Nigeria has been attributed to lack of adequate resource information (Fagbami, 1986; Medugu, 2006). A sound resource judgment is a prerequisite for adequate land use planning. Recently emphasis has shifted from uplands to floodplains due to characteristics such as fine-scale slopes, stability of moisture conditions, climate and nutrient supplies through fluvial processes (Akamigbo et al., 2001; Idoga and Azakagu, 2008, Moustakidis, 2016). Rivers at some time during the year overflows its banks, leading to differential deposition of parent material. The deposition pattern is influenced by fine-scale topographic variation and distance from the river channel which results in large differences in patterns of silt and clay distribution (Stoeckel and Miller-Goodman, 2001; Ajiboye et al., 2012). Hence, the complex natures of alluvial soils have given rise to large variations in properties over short distances; a major determinant of soil productivity (Udo et al., 2006, Dengiz, 2010). The diverse characteristics of depositional lowlands perhaps had triggered the interest of scientists to embark on studies related to toposequence (Lima et al., 2002; Umeugochukwu, 2009; Layzell and Eppes, 2012).

The Lower Niger floodplain at Atani is drained mainly by the River Niger and its tributaries and is highly cultivated. Due to annual flooding, soils formed along the slope often vary greatly in pedological, chemical and mineralogical characteristics as well as land use. Some attempts made to characterize and classify the soils have

Please cite as: Okenmuo F.C., Anochie C.O., Ukabiala M.E., Asadu C.L.A., Kefas P.K. and Akamigbo F.O.R. (2020). Classification and assessment of agricultural potential of the lower Niger floodplain soils of Atani, southeastern Nigeria. Agro-Science, 19 (3), 51-61. DOI: https://doi.org/10.4314/as.v19i3.9 
highlighted such variations in properties (Asadu, 1989, Buri et al., 1999, Igwe et al., 2006) and identified Ultisols and Inceptisols in Atani floodplains following the U.S. Soil Taxanomy.

However, no study has considered the finescale topography and distance from river channel which often influences land use in the region. Such systematic classification and characterization will inform land users and managers on how best to use and protect such areas. Thus, the objective of this study was to evaluate the properties of the soils, classify, establish fertility capability classes and suggest management options in relation to land positions for their sustainable productivity.

\section{MATERIALS AND METHODS \\ Study Site}

The study site was the bank of the River Niger at Atani in Ogbaru LGA of Anambra State. It lies within latitudes $5^{\circ} 58^{\prime}$ and $6^{\circ} 06^{\prime} \mathrm{N}$ and longitudes $6^{\circ} 41^{\prime} \mathrm{E}$ and $6^{\circ} 51^{\prime} \mathrm{E}$ along the Lower River Niger Basin south of Onitsha town, $18.5 \mathrm{~km}$ west of Nnewi town and is part of a floodplain which extends more than $1000 \mathrm{~km}^{2}$ (Figure 1). The annual rainfall of the area ranges from $1500 \mathrm{~mm}$ to 3000 $\mathrm{mm}$ and annual temperature from $20.8^{\circ} \mathrm{C}$ to $35^{\circ} \mathrm{C}$ (Nigeria Meteorological Agency, 2013). The seasonal wet (April to October) and dry (November to March) tropical climates subject the site to flooding during the rainy season and complete drying during the dry season (Okeke et al., 2011). Hence the soil moisture regime is aquic while the soil temperature regime is isohyperthermic. The parent material is Alluvium from the Niger River sediments. The dominant clay mineral is kaolinite while smectite, illite, quartz and aluminiumsmectite have also been identified (Asadu, 1989, Igwe et al., 2006). Ogbaru is predominantly an agrarian community. The major arable crops grown include yam (Dioscorea spp.), cassava (Manihot esculenta), rice (Oryza sativa), cocoyam (Colocasia esculenta), maize (Zea mays), melon (Citrullus vulgaris) and vegetables. Tree crops include oil palm (Elaeis guineensis), raphia palm (Raphia spp.), coconut (Cocus nucifera), citrus (Citrus spp.), etc.

\section{Field Work}

A reconnaissance survey of the area was carried out with the aid of a topographic map of scales 1:100,000, soil maps and soil reports. The topographic map was obtained from the Department of Geology, University of Nigeria, Nsukka. Representative soil geomorphic units were identified. Due to sedimentation, the floodplain has a slightly convex cross-section and the identification of the different physiographic units followed this landform shape, alongside its accessibility and land use (Figure 2 and Table 1). All sampled points were geo-referenced with the Garmin Geographic Positioning Systems (GPS) and designated $\mathrm{OGB}_{1}, \mathrm{OGB}_{2}, \mathrm{OGB}_{3}$ for levee crest, levee slope and flood basin respectively. Each of the pits representing the units was dug to a depth of $2 \mathrm{~m}$. The morphological characteristics of each profile pit such as soil depth, drainage, colour, mottle, structure, consistence, concretions, cutans, pores, roots and horizon boundary were described in the field, according to FAO's (2006) guideline. Bulk samples for physico-chemical analyses were collected from the identified genetic horizons. The bulk samples were later air-dried, crushed and sieved through a $2 \mathrm{~mm}$ mesh sieve. The fine earth fraction was subjected to standard laboratory procedures.

\section{Laboratory Procedures}

Particle size distribution was determined by hydrometer method as described by Gee and Bauder (1986) using sodium hexametaphosphate as a dispersant. The $\mathrm{pH}$ was determined in distilled water using soil/liquid ratio of 1: 2.5 (Gee and Bauder (1986). Organic carbon was determined by the Walkley and Black method described by Nelson and Sommers (1982). Total nitrogen (TN) was determined by the Kjeldahl method (Bremner and Mulvaney, 1982). Available phosphorus (P) was measured by Bray II extraction method (Page et al., 1982). The exchangeable bases were determined by the complexometric titration method as described by Chapman (1982). Exchangeable acidity was determined by the titrimetric method after extraction with 1N KCl (Mclean, 1982). Exchangeable hydrogen $\left(\mathrm{H}^{+}\right)$was obtained using 5 drops of phenolphthalein indicator titrated with $0.05 \mathrm{~N} \mathrm{NaOH}$ and $0.05 \mathrm{~N} \mathrm{HCl}$ to obtain end point. Aluminium $\left(\mathrm{Al}^{3+}\right)$ was obtained using $10 \mathrm{mls}$ of $4 \%$ $\mathrm{NaF}$ and titrated with $0.05 \mathrm{HCl}$ while the sum of exchangeable bases and exchange acidity was taken as the effective cation exchange capacity (ECEC). The CEC was determined by the ammonium acetate method of Jackson (1958). Percentage aluminium saturation was calculated using the formula:

$$
\% \text { Al saturation }=\frac{\text { Exchangeable } A l}{E C E C} \times \frac{100}{1}
$$

Percentage base saturation (BS) was calculated by obtaining the sum of the exchangeable bases and dividing by the ECEC, and then multiplying the quotient by 100 , thus:

$$
B S=\frac{T E B}{E C E C} \times \frac{100}{1}
$$

where TEB is total exchangeable bases $\left(\mathrm{cmol} \mathrm{kg}^{-1}\right)$ and ECEC is effective cation exchange capacity $\left(\mathrm{cmol} \mathrm{kg}^{-1}\right)$ of the soil. 

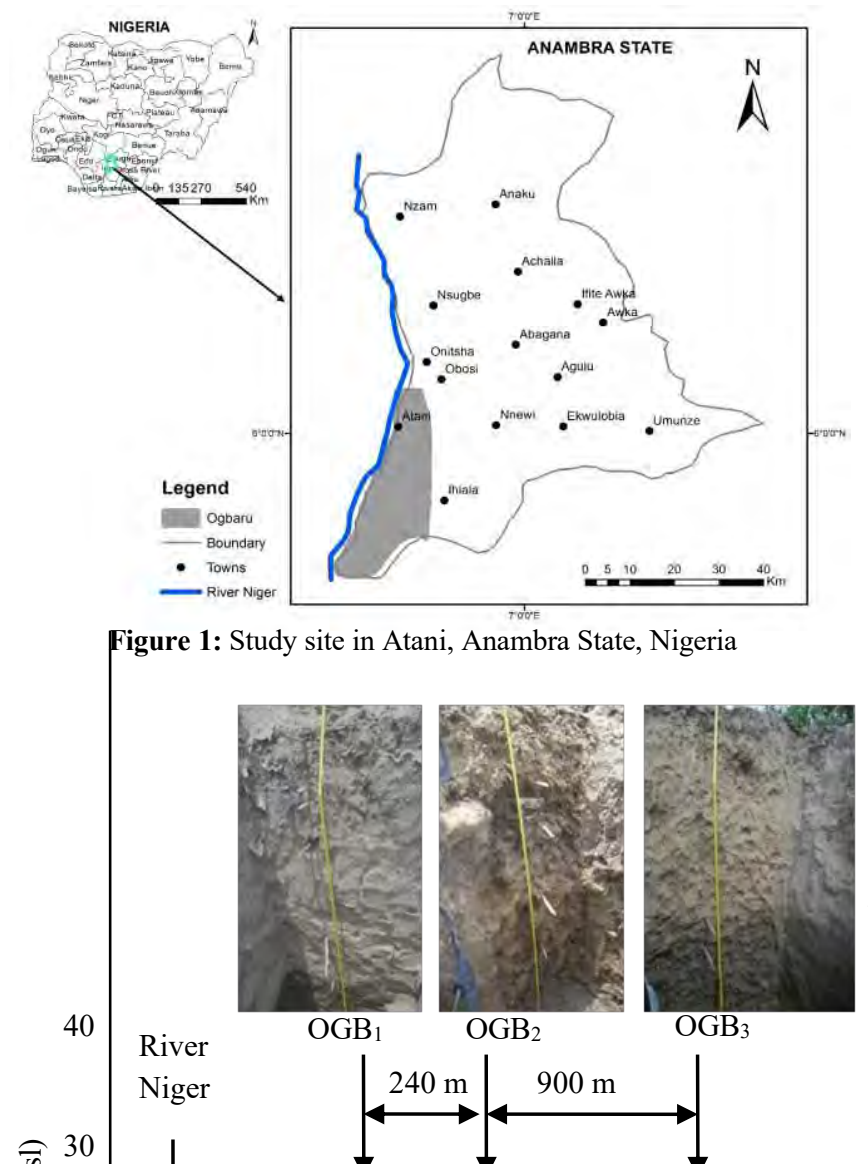

where is ESP is exchangeable sodium percentage, (\%), $\mathrm{Na}$ is measured exchangeable $\mathrm{Na}\left(\mathrm{cmol} \mathrm{kg}^{-1}\right)$, and CEC is cation exchange capacity $\left(\mathrm{cmol} \mathrm{kg}^{-1}\right)$.

The Carbon/Nitrogen ratio was calculated from the contents of carbon and nitrogen in the samples. The soils were classified according to the USDA Keys to Soil Taxanomy (Soil Survey Staff, 2014) and correlated with the FAO/IUSS World Reference Base (WRB) for Soil Resources (FAO/IUSS Working Group, 2015). Fertility capability classifications of the soils was done following the procedure documented by Sanchez et al. (1982).

\section{RESULTS AND DISCUSSION}

The results of the study and important discussions are summarized below.

\section{Soil Morphology and Genesis of Ogbaru Floodplain Soils}

The results of the morphological properties of Atani floodplain soils are shown in Table 2. The soils are derived from recent alluvial deposits of the River Niger. The pedons were deep and poorly drained. At the time of examination, moist subsurface horizons were observed in pedons $\mathrm{OGB}_{1}$ and $\mathrm{OGB}_{3}$.

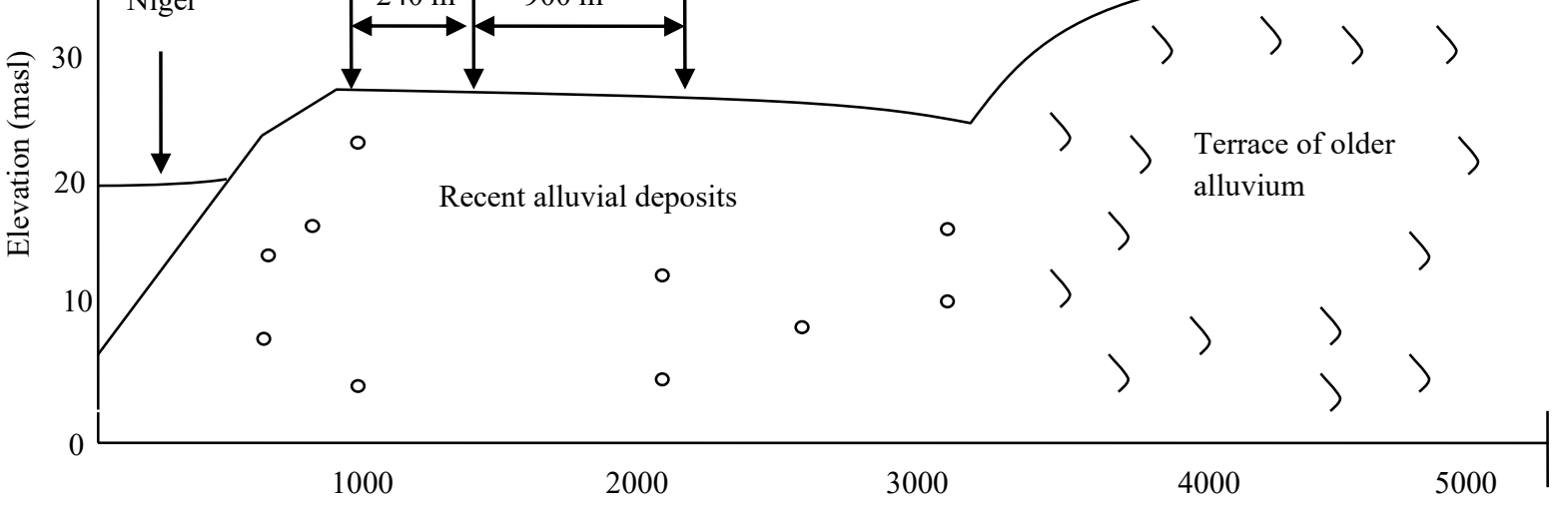

Distance (m)

Figure 2: Schematic representation of the area showing topographic sequence and the distance from the river channel

Table 1: Identification and land use of the studied profiles

\begin{tabular}{|c|c|c|c|}
\hline Profile & Position/Coordinate/ slope & Elevation $(\mathrm{m})$ & Land use \\
\hline $\mathrm{OGB}_{1}$ & $\begin{array}{l}\text { Natural levee (Latitude } 6^{\circ} 00^{\prime} 23.4 \mathrm{~N} \text {, } \\
\left.\text { Longitude } 6^{\circ} 44^{\prime} 26.0^{\prime \prime} \mathrm{E}\right) / 1.5 \%\end{array}$ & 27 & $\begin{array}{l}\text { Grassland; mainly elephant grass (Pennisetum purpureum). } \\
\text { Surrounding area is used for vegetable cultivation. }\end{array}$ \\
\hline $\mathrm{OGB}_{2}$ & $\begin{array}{l}\text { Levee slope (Latitude } 6^{\circ} 00^{\prime} 23.3 \mathrm{~N} \text {, } \\
\left.\text { Longitude } 6^{\circ} 44^{\prime} 33.6^{\prime \prime} \mathrm{E}\right) / 3 \%\end{array}$ & 26 & $\begin{array}{l}\text { Under yam and cassava cultivation. Other uses include: oil palm, } \\
\text { bananas and plantain cultivation. }\end{array}$ \\
\hline $\mathrm{OGB}_{3}$ & $\begin{array}{l}\text { Flood basin (Latitude } 5^{\circ} 599^{\prime} 55.7^{\prime \prime} \mathrm{N} \\
\left.\text { Longitude } 6^{\circ} 44^{\prime} 40.2^{\prime \prime} \mathrm{E}\right) / 6 \%\end{array}$ & 23 & $\begin{array}{l}\text { Fallow as at the time of examination but evidence of previous yam } \\
\text { cultivation. Other vegetation include: oil palm, bamboo, snake } \\
\text { weed (Euphobia hirta), elephant grass (Pennisetum purpureum), } \\
\text { Calapogonuim mucunoides, Ageratum spp., etc. }\end{array}$ \\
\hline
\end{tabular}

Exchangeable sodium percentage was obtained by dividing the respective amount of sodium of soil by the ECEC and multiplying the quotient by 100 :

$$
E S P=\frac{N a^{+}}{E C E C} \times \frac{100}{1}
$$

This is an indication of ground water fluctuations within the upper $2 \mathrm{~m}$ depth of the pedons. Additionally, the presence of stagnic or gleyic properties in all the profiles, as designated by ' $\mathrm{g}$ ' is caused by prolonged period of water stagnation due 
to river flooding and previously stated ground water fluctuations. Under the aquic condition, $\mathrm{Fe}$ and $\mathrm{Mn}$ become reduced to form redoximorphic features (Esu, 2010; Okenmuo, 2015). Such feature was only absent between $25-50 \mathrm{~cm}$ depth of $\mathrm{OGB}_{2}$ and suggests that soluble Fe was lost in the layer. The stratification of the profiles with depth presented a sequence of various thin layers which bore the characteristics of the predominant environmental conditions during deposition. According to the munsell notation, the predominant hue was 10YR (yellowish) which was associated with the hydromorphic conditions and the presence of oxidized ferric iron oxides or some organic matter. In $\mathrm{OGB}_{1}$, the surface colour (moist) was characterized by brownish black (10YR 3/2), dull yellowish brown (10YR 4/3) in $\mathrm{OGB}_{2}$ and dark brown (10YR 3/4) in $\mathrm{OGB}_{3}$. The dark brown and blackish-coloured soil surface colour suggests that organic matter decomposition was dominant at $\mathrm{OGB}_{1}$ and $\mathrm{OGB}_{2}$ under the prevailing environmental condition. This is in line with Ahukaemere et al. (2016), Abagyeh et al. (2017) and D'Elia et al. (2017) who observed that dark soil colours in sedimentary soils signaled increased SOC contents associated with annual flooding. The subsurface layers however graded into shades of brown, dark brown and yellowish brown colours showing various patterns of sedimentation and occurrence of pigmentary materials of hydrated iron oxide and water-soluble organic matter. These results are buttressed by similar works in flooded environments (Sakar et al., 2001; Schiavo et al., 2012; D'Elia et al., 2017). Platy structure admixture with subangular blocky structure was observed at topsoil of $\mathrm{OGB}_{1}$ while subangular blocky structures and single grained structures were common down the profile. The platy structure may be related to parent material or compaction caused by prolonged submergence period and the influence of deposited organic material (NRCS, 2011; Abagyeh et al., 2017). Pedons OGB 2 and $\mathrm{OGB}_{3}$ had subangular blocky structures at the surface and subsurface except in $\mathrm{OGB}_{2}$ with a massive structure at $25-50 \mathrm{~cm}$ depth. The massive structure was designated a cambic horizon. Underneath the layer, at 50-60 $\mathrm{cm}$ depth, large stones of bricks reflected human activities with machinery or hand tool and was designated Bwg. These conditions will restrict water movement and workability of the soils in this position.

Apart from the levee soil $\left(\mathrm{OGB}_{1}\right)$ which was loose within $54-150 \mathrm{~cm}$, the other profiles have a friable to firm consistence; indicating moderate water retention in the soils. Other features such as fine to coarse roots were observed in all the horizons of the three profiles except below $54 \mathrm{~cm}$ depth of $\mathrm{OGB}_{1}$. Artefacts such as pottery, bricks and charcoal were observed at the levee $\left(\mathrm{OGB}_{1}\right)$ and the levee-slope $\left(\mathrm{OGB}_{2}\right)$, which was attributed to flood deposition and past human activities in the area. $\mathrm{OGB}_{1}$ is characterized by a simple $\mathrm{A}$ and $\mathrm{C}$ horizons without diagnostic horizons due to their early stage of development. A little more development was observed at $\mathrm{OGB}_{2}$ and $\mathrm{OGB}_{3}$ with the development of cambic B-horizons, suggesting their older age. There was no diagnostic epipedon in surface soils of all the soil profiles, except in $\mathrm{OGB}_{2}$, which had an ochric epipedon. Ochric epipedon has a Munsell color value of 4 or more when moist, and 6 or more when dry; or chroma of 4 or more; or includes an A or Ap horizon that has both a low color value and low chroma (Soil Survey Staff, 2014). Horizon designations of $\mathrm{OGB}_{1}$ placed depths $14-39 \mathrm{~cm}$ as a buried soil horizon because they are underneath a deposit of a new material. However, the mantle does not reach the minimum requirement of $50 \mathrm{~cm}$ to qualify as a buried soil (Soil Survey Staff, 2014).

Table 2: Morphological properties of Ogbaru floodplain soils

\begin{tabular}{|c|c|c|c|c|c|c|c|}
\hline Pedon & Horizon & Depth $(\mathrm{cm})$ & Colour* & Mottle & Structure & Consistency* & Other features \\
\hline \multirow[t]{6}{*}{$\mathrm{OGB}_{1}$} & $\mathrm{Ag}$ & $0-14$ & 10YR 3/2 & $2.5 Y R 4 / 6$ & $1 \mathrm{p} / \mathrm{msbk}$ & $\mathrm{fr}$ & $1 \mathrm{fr}, \mathrm{A}$ \\
\hline & $\mathrm{Abg}$ & $14-39$ & $10 \mathrm{YR} 4 / 2$ & $2.5 \mathrm{YR} 4 / 2$ & $3 \mathrm{csbk}$ & fi & $2 \mathrm{mcr}, \mathrm{A}$ \\
\hline & $\mathrm{Cg} 1$ & $39-54$ & $10 \mathrm{YR} 4 / 3$ & $2.5 \mathrm{YR} 4 / 8$ & $3 \mathrm{csbk}$ & $\mathrm{fr}$ & $2 \mathrm{mcr}$ \\
\hline & $2 \mathrm{Cg} 2$ & $54-110$ & $10 \mathrm{YR} 4 / 6$ & $2.5 \mathrm{YR} 4 / 6$ & sg & lo & - \\
\hline & $2 \mathrm{Cg} 3$ & $110-150$ & 10YR 6/6 & $2.5 \mathrm{YR} 3 / 6$ & sg & lo & A \\
\hline & $3 \mathrm{Cg} 4$ & $150-200$ & $10 \mathrm{YR} 4 / 3$ & $2.5 \mathrm{YR} 5 / 8$ & $2 \mathrm{msbk}$ & fr & A \\
\hline \multirow[t]{6}{*}{$\mathrm{OGB}_{2}$} & Apg & $0-25$ & $10 \mathrm{YR} 4 / 3$ & $5 \mathrm{YR} 4 / 6$ & $2 \mathrm{csbk}$ & fr & $3 \mathrm{cr}$ \\
\hline & $\mathrm{Bw}$ & $25-50$ & $10 \mathrm{YR} 4 / 4$ & - & $\mathrm{m}$ & vfi & $1 \mathrm{fr}, \mathrm{A}$ \\
\hline & ${ }^{\wedge}$ Bwg & $50-65$ & $10 Y R 3 / 3$ & $5 Y R 4 / 8$ & $3 \mathrm{csbk}$ & vfi & $1 \mathrm{fr}, \mathrm{A}$ \\
\hline & Bwg & $65-101$ & $10 \mathrm{YR} 3 / 3$ & $5 Y R 4 / 8$ & $2 \mathrm{msbk}$ & $\mathrm{fr}$ & $1 \mathrm{fr}$ \\
\hline & $\mathrm{Cg}$ & $101-140$ & $10 Y R 5 / 4$ & $2.5 \mathrm{YR} 2 / 4$ & $2 \mathrm{msbk}$ & fr & \\
\hline & $2 \mathrm{Cg}$ & $140-200$ & $10 \mathrm{YR} 6 / 3$ & 7.5YR 3/4 & $2 \mathrm{msbk}$ & fi & A \\
\hline \multirow[t]{6}{*}{$\mathrm{OGB}_{3}$} & Apg & $0-14$ & $10 \mathrm{YR} 3 / 4$ & 5YR 5/8 & $2 \mathrm{msbk}$ & fr & $3 \mathrm{cr}$ \\
\hline & $\mathrm{ABg}$ & $14-30$ & $10 Y R 3 / 4$ & 5YR 5/8 & $2 \mathrm{msbk}$ & $\mathrm{fi}$ & $1 \mathrm{cr}$ \\
\hline & $\mathrm{Bg} 1$ & $30-84$ & 10 YR $6 / 4$ & 5YR 5/6 & $2 \mathrm{msbk}$ & vfr & $1 \mathrm{fr}$ \\
\hline & $\mathrm{Bg} 2$ & $84-116$ & 10YR 6/4 & $5 Y R 5 / 6$ & $2 \mathrm{msbk}$ & vfr & $1 \mathrm{fr}$ \\
\hline & $\mathrm{CBg}$ & $116-135$ & $10 \mathrm{YR} 5 / 4$ & $5 Y R 2 / 4$ & $1 \mathrm{msbk}$ & fr & $1 \mathrm{fr}$ \\
\hline & $\mathrm{Cg}$ & $135-200$ & $10 \mathrm{YR} 5 / 4$ & 5YR 3/4 & $2 \mathrm{msbk}$ & $\mathrm{fr}$ & $1 \mathrm{fr}$ \\
\hline
\end{tabular}

作 csbk, coarse subangular blocky; msbk, medium subangular blocky; fsbk, fine subangular blocky; p, platy; m, massive, Consistence: lo, loose; fr, friable; vfr, very friable; fi, firm; vfi, very firm. Roots: 1 , few; 2, moderate; 3, many; fr, fine roots; cr, coarse roots. Pores: mp, many pores; fp, few pores; A, Artefacts 


\section{Physical Properties of Ogbaru Floodplain Soils}

The particle size distribution of the soils is shown (Table 3). All three pedons show sequences of fluvial sands, silts and clay depositions. Textural classes were clay loam to sand $\left(\mathrm{OGB}_{1}\right)$, clay loam to sandy clay loam $\left(\mathrm{OGB}_{2}\right)$ and clay loam to sandy loam $\left(\mathrm{OGB}_{3}\right)$. The varied textures of lowland soils have been related to parent material and topographic position (Akamigbo, 2001; Nwite et al., 2012; Obalum et al., 2014; Kefas et al., 2016; Obalum and Chibuike, 2017). At $\mathrm{OGB}_{1}$, parent materials were dominantly total sand which was higher in the pedon with average values of $57 \%$ and clay fractions were lowest. Silt contents were higher at the $\mathrm{OGB}_{2}$ by average values of $37 \%$ while at $\mathrm{OGB}_{3}$, the total sand fraction was higher in the pedon by $46 \%$. The distinct dominance of textural compositions is indicative of the differential deposition of particles during floods, from coarser particles at the levee and finer particles further away from the river channel. This finding agrees with Ukaegbu and Akamigbo (2004) and Obalum et al. (2011) that the natural levees (upper land positions) are dominated by sand and silt, while silt and clay dominated downslope, due to the lateral movement of the sedimentladen water down-slope. In this study, the burial of soils surface by a recent deposit of $14 \mathrm{~cm}$ thickness at the levee position and erosion of clay particles at the epipedon of the floodplain basin may be responsible for decline of clay and high sand-sized particles at the positions. The dominance of fine sand over coarse sand and the higher silt contents in the soil compared to adjacent soils within the region have been reported (Igwe et al., 2006). While clay was slightly depleted in the A-horizon of all the profiles, it gradually increased at the subsurface horizons. This may be associated with sediment deposition process, removal of clay and silt through runoff during intense rainfall as common in the area, as well as illuviation of clay due to percolation of flood waters (Igwe et al., 2006). However, the increase in clay within the respective depths of $25-65 \mathrm{~cm}$ of pedon $\mathrm{OGB}_{2}$ and $14-30 \mathrm{~cm}$ of pedon $\mathrm{OGB}_{3}$ was not designated an argillic horizon because the clay maxima was reached within $30 \mathrm{~cm}$ of surface, and the clay content decreased downward from the clay maxima. In addition, the increases appear to be related to deposition rather than pedogenic processes which require enough time to alter the original sediment distribution. This finding corroborates observations of Markewich et al. (1988) in soils developed in Holocene-age alluvium in east-central Alabama, classified as Hapludults instead of as Fluventic Dystrochrepts. At $\mathrm{OGB}_{1}$, lithological discontinuity was placed at depth 54-150 $\mathrm{cm}$, where there is a significant change in relative compositions of sand, silt, and clay. Such layers are caused by abrupt changes in parent material, agent and energy of transportation and deposition.

\section{Soil Chemical Properties}

Table 4 shows the chemical properties of the soils. The $\mathrm{pH}$ values ranged from 4.8 to 6.2 and 3.7 to 5.9 in distilled water and $1 \mathrm{M} \mathrm{KCl}$ respectively. They were very strongly to slightly acidic in reaction (in $\mathrm{H}_{2} \mathrm{O}$ ) (Enwezor et al., 1989). Topsoil of $\mathrm{OGB}_{1}$ and $\mathrm{OGB}_{2}$ were strongly acidic and very strongly acidic with values 5.1 and 4.9 respectively while the subsurface horizons of both pedons irregularly increased to slight acidity. In contrast to this, topsoil reaction was moderately acidic (6.0) at $\mathrm{OGB}_{3}$ while the subsurface ranged from strongly acidic to moderately acidic (5.4-5.9). Low $\mathrm{pH}$ and its gradual increases with depth have been observed in floodplains of West Africa (Buri et al., 1999). Considering the $\mathrm{pH}$ values at the topsoil of each unit, the order of nutrient loss of cations from the pedons will be $\mathrm{OGB}_{2}>\mathrm{OGB}_{1}>\mathrm{OGB}_{3}$. The low $\mathrm{pH}$ and its slight tendency towards neutrality down the profiles may be associated with horizons textural compositions, their cation retention abilities and leaching consequent on the high rainfall cum water table activities in this region. Notwithstanding, at this $\mathrm{pH}$ range, most crops can still thrive because the $\mathrm{H}^{+}$concentration does not inhibit cation absorption. When the $\mathrm{pH}$ values in water are compared to the $\mathrm{pH}$ values in $\mathrm{KCl}$, they were observed to be higher (Table 4). This indicates the dominance of a net negative charge in the soils and the lowering of soil $\mathrm{pH}$ due to increased neutrality of salt concentration to 0.1 or $1 \mathrm{M}$ (Bohn et al., 2001; Silva Neto et al., 2015). At $\mathrm{OGB}_{1}$, exchangeable $\mathrm{Ca}$ and $\mathrm{Mg}$ ranged from 2.6 to 6.2 and 1.6 to 6.8 $\mathrm{cmol}_{\mathrm{c}} \mathrm{kg}^{-1}$ respectively, whereas exchangeable $\mathrm{Na}$ and $\mathrm{K}$ varied from 1.5 to 1.8 and 1.6 to $2.2 \mathrm{cmol}$ $\mathrm{kg}^{-1}$ respectively. Based on the ratings of Enwezor et al. (1989), the soils are categorized as low to moderate with respect to $\mathrm{Ca}$ and moderate to high with respect to $\mathrm{Mg}$. In terms of $\mathrm{Na}$, the soil was categorized as high while $\mathrm{K}$ was very high. At $\mathrm{OGB}_{2}$, the value of exchangeable $\mathrm{Ca}$ and $\mathrm{Mg}$ ranged from 4.8 to 8.2 and 2.2 to $4.2 \mathrm{cmol} \mathrm{kg}^{-1}$ respectively, whereas $\mathrm{Na}$ and $\mathrm{K}$ ranged from 1.0 to 2.5 and 1.7 to $3.8 \mathrm{cmol} \mathrm{kg}^{-1}$ respectively. Hence the soils were categorized in accordance to Enwezor et al. (1989) as low to moderate for Ca, moderate to high for $\mathrm{Mg}$, high in terms of $\mathrm{Na}$ and very high in terms of $\mathrm{K}$. At $\mathrm{OGB}_{3}$, the value of exchangeable $\mathrm{Ca}$ and $\mathrm{Mg}$ ranged from 2.8 to 5.0 and 2.0 to $5.4 \mathrm{cmol}$ $\mathrm{kg}^{-1}$ respectively, whereas $\mathrm{Na}$ and $\mathrm{K}$ ranged from 1.4 to 3.0 and 1.2 to $4.2 \mathrm{cmol} \mathrm{kg}^{-1}$ respectively. Hence the soils were categorized in accordance to Enwezor et al. (1989) as low for Ca, moderate to high for $\mathrm{Mg}$, high to very high in terms of $\mathrm{Na}$ and very high in terms of $\mathrm{K}$. The dominant cations on the exchange complex were $\mathrm{Ca}^{2+}$ and $\mathrm{Mg}^{2+}$ whereas $\mathrm{K}^{+}$and sodium $\mathrm{Na}^{+}$were observed to be less dominant on the exchange complex but were higher 
Table 3: Particle size distribution $\left(\mathrm{g} \mathrm{kg}^{-1}\right)$ of Ogbaru floodplain soils

\begin{tabular}{|c|c|c|c|c|c|c|c|c|}
\hline Position of profile & Horizon & Depth $(\mathrm{cm})$ & Clay & Silt & Fine sand & Coarse sand & Total sand & Textural class \\
\hline \multirow[t]{6}{*}{$\mathrm{OGB}_{1}$} & $\mathrm{Ag}$ & $0-14$ & 260 & 290 & 330 & 120 & 450 & Loam \\
\hline & $\mathrm{Abg}$ & $14-39$ & 360 & 390 & 200 & 40 & 250 & Clay loam \\
\hline & $\mathrm{Cg} 1$ & $39-54$ & 180 & 290 & 510 & 20 & 530 & Sandy loam \\
\hline & $2 \mathrm{Cg} 2$ & $54-110$ & 80 & 10 & 850 & 60 & 910 & Sand \\
\hline & $2 \mathrm{Cg} 3$ & $110-150$ & 60 & 10 & 600 & 330 & 930 & Sand \\
\hline & $3 \mathrm{Cg} 4$ & $150-200$ & 300 & 350 & 300 & 50 & 350 & Clay loam \\
\hline \multirow[t]{6}{*}{$\mathrm{OGB}_{2}$} & Apg & $0-25$ & 280 & 370 & 280 & 60 & 350 & Clay loam \\
\hline & $\mathrm{Bw}$ & $25-50$ & 300 & 370 & 260 & 60 & 320 & Clay loam \\
\hline & ${ }^{\wedge}$ Bwg & $50-65$ & 340 & 350 & 270 & 40 & 310 & Clay loam \\
\hline & $\mathrm{BCg}$ & $65-101$ & 220 & 270 & 470 & 30 & 500 & Sandy clay loam \\
\hline & $\mathrm{Cg} 1$ & $101-140$ & 260 & 390 & 340 & 10 & 350 & Loam \\
\hline & $\mathrm{Cg} 2$ & $140-200$ & 340 & 450 & 180 & 30 & 210 & Clay loam \\
\hline \multirow[t]{6}{*}{$\mathrm{OGB}_{3}$} & Apg & $0-14$ & 120 & 350 & 520 & 10 & 530 & Sandy loam \\
\hline & $\mathrm{ABg}$ & $14-30$ & 300 & 290 & 380 & 30 & 410 & Clay loam \\
\hline & $\mathrm{Bg} 1$ & $30-84$ & 220 & 430 & 330 & 10 & 340 & Loam \\
\hline & Bg2 & $84-116$ & 100 & 270 & 620 & 10 & 630 & Sandy loam \\
\hline & $\mathrm{CBg}$ & $116-135$ & 180 & 370 & 430 & 20 & 450 & Loam \\
\hline & $\mathrm{Cg}$ & $135-200$ & 320 & 290 & 370 & 20 & 390 & Clay loam \\
\hline
\end{tabular}

Table 4: Chemical properties of Ogbaru floodplain soils

\begin{tabular}{|c|c|c|c|c|c|c|c|c|c|c|c|c|c|c|c|c|c|c|c|}
\hline \multirow[t]{3}{*}{ Horizon } & \multirow{3}{*}{$\begin{array}{l}\text { Depth } \\
\text { (cm) }\end{array}$} & \multicolumn{2}{|c|}{ Soil pH } & $\mathrm{Ca}$ & Mg & $\mathrm{Na}$ & K & ECEC & TEB & \multirow{3}{*}{$\begin{array}{c}\mathrm{TN} \\
\left(\mathrm{g} \mathrm{kg}^{-1}\right)\end{array}$} & \multirow{3}{*}{$\begin{array}{c}\text { CEC } \\
\left(\mathrm{cmol}_{\mathrm{c}} \mathrm{kg}^{-1}\right)\end{array}$} & \multirow{3}{*}{$\begin{array}{c}\mathrm{OC} \\
\left(\mathrm{g} \mathrm{kg}^{-1}\right)\end{array}$} & \multirow{3}{*}{$\begin{array}{c}\text { Av.P } \\
\left(\mathrm{mg} \mathrm{kg}^{-1}\right)\end{array}$} & \multicolumn{2}{|c|}{ EA } & \multirow[t]{3}{*}{ Al Sat. } & \multirow{2}{*}{\multicolumn{2}{|c|}{ BS ESP }} & \multirow{3}{*}{$\begin{array}{l}\mathrm{C} / \mathrm{N} \\
\text { ratio }\end{array}$} \\
\hline & & $\mathrm{H}_{2} \mathrm{O}$ & $\mathrm{KCl}$ & \multirow{2}{*}{\multicolumn{6}{|c|}{$\left(\mathrm{cmol}_{\mathrm{c}} \mathrm{kg}^{-1}\right)$}} & & & & & $\mathrm{H}^{+}$ & $\mathrm{Al}^{3+}$ & & & & \\
\hline & & & & & & & & & & & & & & \multicolumn{2}{|c|}{$\left(\mathrm{cmol}_{\mathrm{c}} \mathrm{kg}^{-1}\right)$} & & \multicolumn{2}{|l|}{$(\%)$} & \\
\hline Profile 1 & $\left(\mathrm{OGB}_{1}\right)$ & & & & & & & & & & & & & & & & & & \\
\hline $\mathrm{Ag}$ & $0-14$ & 5.1 & 4.3 & 6.0 & 6.8 & 1.8 & 2.2 & 19 & 16.8 & 1.12 & 29.2 & 14.3 & 15.86 & 1.4 & 0.8 & 4.2 & 88 & 9 & 13 \\
\hline Abg & $14-39$ & 5.1 & 3.9 & 6.2 & 3.4 & 1.8 & 1.8 & 15.6 & 13.2 & 0.98 & 39.6 & 11.5 & 7.46 & 0.8 & 1.6 & 10.3 & 84 & 12 & 33 \\
\hline $\mathrm{Cg} 1$ & $39-54$ & 5.3 & 4.0 & 4.4 & 2.8 & 1.6 & 1.6 & 12.6 & 10.4 & 0.42 & 30.8 & 3.4 & 9.33 & 1.4 & 0.8 & 6.3 & 83 & 13 & 8 \\
\hline $2 \mathrm{Cg} 2$ & $54-150$ & 6.1 & 4.7 & 2.6 & 1.6 & 1.5 & 1.6 & 9.5 & 7.3 & 0.14 & 11.6 & 2.6 & 4.66 & 1.8 & 0.4 & 4.2 & 76 & 16 & 19 \\
\hline $3 \mathrm{Cg} 3$ & $150-200$ & 4.8 & 3.7 & 4.8 & 2.6 & 1.8 & 1.8 & 17 & 11.0 & 0.14 & 32.4 & 2.9 & 12.12 & 2.4 & 3.6 & 21.2 & 65 & 11 & 20 \\
\hline Profile 2 & $\left(\mathrm{OGB}_{2}\right)$ & & & & & & & & & & & & & & & & & & \\
\hline Apg & $0-25$ & 4.9 & 4.0 & 5.8 & 2.2 & 2.5 & 3.0 & 14.5 & 13.5 & 0.84 & 36.8 & 15.2 & 13.99 & 0.4 & 0.6 & 4.1 & 93 & 17 & 18 \\
\hline $\mathrm{Bw}$ & $25-50$ & 5.2 & 4.1 & 5.0 & 4.2 & 1.0 & 3.0 & 15.0 & 13.2 & 0.28 & 40.4 & 9.2 & 12.12 & 0.8 & 1.0 & 6.7 & 88 & 7 & 33 \\
\hline Bwg & $50-65$ & 5.4 & 4.9 & 8.2 & 3.2 & 2.0 & 3.6 & 19.0 & 17.0 & 0.70 & 42.4 & 8.3 & 13.99 & 1.6 & 0.4 & 2.1 & 89 & 11 & 12 \\
\hline Bwg & $65-101$ & 6.2 & 4.1 & 7.4 & 3.0 & 1.9 & 3.8 & 17.5 & 16.1 & 0.56 & 30.4 & 12.4 & 31.71 & 0.8 & 0.6 & 3.4 & 92 & 11 & 22 \\
\hline$C^{\prime} g$ & $101-140$ & 6.2 & 4.1 & 6.4 & 3.2 & 2.0 & 2.1 & 14.7 & 13.7 & 0.42 & 25.2 & 8.0 & 2.80 & 0.6 & 0.4 & 2.7 & 93 & 14 & 2 \\
\hline $2 \mathrm{Cg}$ & $140-200$ & 6.2 & 4.9 & 4.8 & 3.0 & 2.0 & 1.7 & 12.5 & 11.5 & 0.40 & 42.6 & 3.6 & 7.47 & 0.8 & 0.2 & 1.7 & 92 & 16 & 9 \\
\hline Profile 3 & $\left(\mathrm{OGB}_{3}\right)$ & & & & & & & & & & & & & & & & & & \\
\hline Apg & $0-14$ & 6.0 & 4.7 & 4.4 & 2.0 & 1.7 & 1.2 & 10.8 & 9.3 & 0.42 & 16.8 & 6.7 & 5.60 & 0.3 & 1.2 & 11.1 & 86 & 16 & 16 \\
\hline $\mathrm{ABg}$ & $14-30$ & 5.4 & 3.9 & 4.0 & 2.6 & 3.0 & 4.2 & 15.8 & 13.8 & 0.42 & 28.8 & 4.2 & 0.93 & 0.8 & 1.2 & 7.6 & 87 & 19 & 10 \\
\hline $\mathrm{Bg} 1$ & $30-84$ & 5.5 & 3.9 & 4.0 & 5.4 & 1.4 & 1.9 & 15.9 & 12.7 & 0.56 & 29.2 & 1.8 & 3.73 & 0.8 & 0.4 & 2.9 & 91 & 9 & 3 \\
\hline Bg2 & $84-116$ & 5.7 & 4.1 & 3.0 & 3.2 & 1.9 & 1.7 & 11.5 & 9.8 & 0.28 & 14.8 & 2.8 & 5.60 & 0.3 & 1.4 & 12.2 & 85 & 17 & 10 \\
\hline CBg & $116-135$ & 5.4 & 3.9 & 5.0 & 3.0 & 1.5 & 1.8 & 13.5 & 11.3 & 0.56 & 28.8 & 0.4 & 1.87 & 0.8 & 1.4 & 10.4 & 84 & 11 & 1 \\
\hline $\mathrm{Cg}$ & $135-200$ & 5.9 & 4.0 & 2.8 & 2.8 & 1.7 & 1.7 & 11.0 & 9.0 & 0.56 & 33.6 & 4.6 & 7.46 & 0.0 & 2.0 & 18.2 & 82 & 15 & 8 \\
\hline
\end{tabular}

Ca, Calcium; Mg, Magnesium; Na, Sodium; K, Potassium; ECEC, effective cation exchange capacity; TEB, total exchangeable bases; TN, total nitrogen;

CEC, apparent cation exchange capacity; OC, organic carbon, OM, organic matter; Av.P, available phosphorus; EA, exchangeable acidity;

Al Sat, aluminium saturation; BS, base saturation; ESP, exchangeable sodium percentage; $\mathrm{C} / \mathrm{N}$, Carbon/Nitrogen ratio

in concent based on rating by Enwezor et al. (1989). The dominance of $\mathrm{Ca}$ and $\mathrm{Mg}$ in flooded lowland soils have been reported (Idoga and Azagaku, 2008; Ogbodo, 2011; Obalum et al., 2012, Nwite et al., 2012, 2017). All profiles were rated similar in exchangeable bases supply except in $\mathrm{OGB}_{3}$ where $\mathrm{Ca}$ was consistently low in all horizons and $\mathrm{Na}$ was very high in the $\mathrm{AB}$ horizon. This indicates similarity in parent material and further influence of erosion at the depressions (Buri et al., 1999). $\mathrm{OGB}_{1}$ had low ECEC at the horizon with a lithological discontinuity within $54-150 \mathrm{~cm}$ depth where coarse sand dominated and at the surface of $\mathrm{OGB}_{3}$ where erosion leads to loss of clay. The irregular distribution of ECEC reflected contribution of exchangeable acidity and the type of clay mineral in each horizon from kaolinite (lower values) to smectite (higher values). The influence exchangeable acidity and clay minerals on the ECEC of floodplain soils have been reported (Asadu, 1989; Buri et al., 1999). Total exchangeable bases were slightly higher at the soil surface except in $\mathrm{OGB}_{3}$. TEB decreased down slope from $\mathrm{OGB}_{1}(16.8), \mathrm{OGB}_{2}$ (13.5) to $\mathrm{OGB}_{3}$ (9.3) and is associated with deposition of basic cations at the levee and levee slope while erosion and leaching may be the reason for the depletion of bases at the flood basin. The irregular distribution of TEB in the subsurface horizons of the soil is clay contents related. An increase in clay entailed higher exchangeable cation levels. This is in line with previous reports of Buri et al. (1999).

The $\mathrm{TN}$ for $\mathrm{OGB}_{1}$ was $1.12 \mathrm{~g} \mathrm{~kg}^{-1}$ at the topsoil, decreasing gradually down the profile. A similar trend of decrease was observed for $\mathrm{OGB}_{2}$ from 0.84 to $0.40 \mathrm{~g} \mathrm{~kg}^{-1}$. The only exception to this was a sharp decrease between depths of $25-50 \mathrm{~cm}$ of $\mathrm{OGB}_{2}$. In contrast, $\mathrm{TN}$ values at $\mathrm{OGB}_{3}$ increased gradually from the topsoil $\left(0.42 \mathrm{~g} \mathrm{~kg}^{-1}\right)$, decreased within 84-110 $\mathrm{cm}$ depth and increased sharply beneath. The TN irregular decrease down the profile has been previously reported in floodplain soils (Akamigbo et al., 2001). The higher values at the topsoil of $\mathrm{OGB}_{1}$ and $\mathrm{OGB}_{2}$ compared to $\mathrm{OGB}_{3}$ 
followed the organic carbon contents. Its inconsistent occurrence at the subsurface may be attributed to leaching. The effective CEC and TEB followed a similar trend to the distribution of the various cations, declining from the levee to the lower positions as associated with varying deposits of cations during flooding and clay distribution pattern. TN contents of the soils were generally very low to moderately low (Enwezor et al., 1989). The low values of TN of soils in the area may be attributed inadequate application of nitrate fertilizers by farmers in the region and other forms of TN losses associated with floods.

The value for the CEC due to the clay fraction (clay CEC) value was highest at $\mathrm{OGB}_{2}$, ranging from 25.2 to $42.6 \mathrm{cmol} \mathrm{kg}^{-1}$, followed by $\mathrm{OGB}_{3}$ which ranged from 14.8 to $33.6 \mathrm{cmol} \mathrm{kg}^{-1}$ and $\mathrm{OGB}_{1}$ which ranged from 11.6 to $39.6 \mathrm{cmol} \mathrm{kg}^{-1}$. They were rated high to very high, moderate to high and low to high respectively (Enwezor et al., 1989). At the topsoil region, the values were higher at $\mathrm{OGB}_{2}\left(36.8 \mathrm{cmol} \mathrm{kg}^{-1}\right)$ and lowest at the $\mathrm{OGB}_{3}$ $\left(16.8 \mathrm{cmol} \mathrm{kg} \mathrm{kg}^{-1}\right.$ ) due to erosion of clay at the depression. The near absence of clay at the lithological discontinuous layer of $\mathrm{OGB}_{1}$ is responsible for the low CEC observed at depth 54$150 \mathrm{~cm}$. The $\mathrm{CEC}$ values followed the order $\mathrm{OGB}_{2}>\mathrm{OGB}_{3}>\mathrm{OGB}_{1}$. This indicates that the soils in the middle-slope were more fertile as influenced by high clay and organic matter contents (Akamigbo et al., 2001; Gregory and Nortcliff, 2012). The value of CEC seems to fairly follow the clay content changes (Table 3 ) in all the pedons.

Based on Chude et al. (2011), very low to high OC values were observed at $\mathrm{OGB}_{1}\left(2.6-14.3 \mathrm{~g} \mathrm{~kg}^{-1}\right)$ and $\mathrm{OGB}_{2}\left(3.6-15.2 \mathrm{~g} \mathrm{~kg}^{-1}\right)$, whereas the values at $\mathrm{OGB}_{3}\left(0.4-6.7 \mathrm{~g} \mathrm{~kg}^{-1}\right)$ were consistently very low to low. Organic carbon contents were highest at the topsoil of $\mathrm{OGB}_{2}\left(15.2 \mathrm{~g} \mathrm{~kg}^{-1}\right)$ compared to $\mathrm{OGB}_{1}$ $\left(14.3 \mathrm{~g} \mathrm{~kg}^{-1}\right)$ and $\mathrm{OGB}_{3}\left(6.7 \mathrm{~g} \mathrm{~kg}^{-1}\right)$ with the lowest values. The high $\mathrm{OC}$ at the levee and levee slope may due to greater deposition of parent material rich in organic matter at the upper zones of the floodplain compared to the flood basin during the recent flood. Also, the values of OC decreased in an irregular pattern from topsoil to subsoil in all the profiles. This irregular decrease in the distribution of $\mathrm{OC}$ with depth in floodplain soils have been reported (Buri et al., 1999; Dengiz, 2010; Eleke et al., 2018). Available P content at was highest at the topsoil of $\mathrm{OGB}_{1}$ (15.86), followed by sharp decrease and irregular increment down the profile. In contrast, available $\mathrm{P}$ values at $\mathrm{OGB}_{2}$ (13.99) and $\mathrm{OGB}_{3}$ (5.6) decreased gradually from the topsoil and peaked at the subsoil. Based on the rating by Chude et al. (2011) the values 4.66 to $15.86 \mathrm{mg} \mathrm{kg}^{-1}$ at $\mathrm{OGB}_{1}$, 2.8 to $31.71 \mathrm{mg} \mathrm{kg}^{-1}$ at $\mathrm{OGB}_{2}$ and 0.93 to $7.46 \mathrm{mg}$ $\mathrm{kg}^{-1}$ at $\mathrm{OGB}_{3}$ were rated low to moderate, very low to high and very low to moderate respectively. The low values of available $\mathrm{P}$ in certain profiles may be related to the low native phosphorus in the parent material, P-fixation, low organic matter and the inability of farmers to apply inorganic fertilizers (Buri et al., 1999; Eleke et al., 2018). These factors may also account for the low available $\mathrm{P}$ at the flood basin compared to the levee and levee slope. The differentia in P-fixation would be explained by the relative wetness of the soils occurring at these topo-positions (Obalum and Chibuike, 2017).

The values of titratable exchangeable acidity $\left(\mathrm{Al}^{3+}+\mathrm{H}^{+}\right)$increased as $\mathrm{pH}$ reduced in most horizons (Table 4). The $\mathrm{Al}^{3+}$ and $\mathrm{H}^{+}$equally constituted the exchangeable acidity except in $\mathrm{OGB}_{3}$ where $\mathrm{Al}^{3+}$ constituted most. The variations may be linked to the nature of parent material. This result agrees with Abreu $\mathrm{Jr}$ et al. (2003) on the presence of $\mathrm{Al}^{3+}$ in soils of high acidity as a function of parent material and soil mineralogy. The resultant variability in the values of exchangeable acidity is attributable to aluminosilicate clay minerals releasing $\mathrm{Al}^{3+}$ and $\mathrm{H}^{+}$ into the soil solution via isomorphous substitution, leaching and nutrient biocycling (Akamigbo and Nnaji, 2011; Ogunwale et al., 2002) under repeated wetting and drying conditions. Exchange acidity and $\mathrm{Al}$ saturation are also useful indices of horizon development of some tropical soils; because exchangeable $\mathrm{Al}$ is relatively less mobile in soil and differential accumulation of may be attributed to in situ clay destruction (Okunsami et al., 1987). Lower aluminum saturation (4.2\%) at horizon $\mathrm{Ag}$ and $2 \mathrm{Cg} 2$ of pedon $\mathrm{OGB}_{1}$ indicates minimal weathering compared to the other horizons in the pedon. Also, moist subsurface horizons (poor internal drainage) observed in $\mathrm{OGB}_{1}(3 \mathrm{Cg} 3)$ and $\mathrm{OGB}_{3}$ seems to be related to greater aluminum saturation in the profiles compared to $\mathrm{OGB}_{2}$. This is similar to findings of Okunsanmi et al. (1987) in alluvial landforms of Central Nigeria. The higher values of aluminium saturation on the levee and flood basin positions implies low cation retention and buffering capacity due to its high leaching potentials. The exchangeable aluminium levels were still within tolerant limits of reserved acidity but must be countered with subsoil liming to ensure adequate crop performance at the two positions.

Higher values of base saturation were obtained at $\mathrm{OGB}_{2}$ and $\mathrm{OGB}_{3}$ compared to $\mathrm{OGB}_{1}$, reflecting the occurrence of basic nutrients in available forms in the solution despite the soil low cation reserves. The base saturation is above $50 \%$ in all positions, an indication of the high fertility of the soils. The ESP values were high to very high in all the profiles based on Enwezor et al. (1989). Sodicity problems are associated with soils with ESP $>15 \%$. Hence the soils may possibly be dispersive and poor in physical and water movement characteristics. 
The $\mathrm{C} / \mathrm{N}$ values were higher at $\mathrm{OGB}_{1}(8-33)$ and $\mathrm{OGB}_{2}(2-33)$ compared to $\mathrm{OGB}_{3}(1-16)$. In this regard, recent flood deposits may have contributed biomass rich in less decomposed carbon. The $\mathrm{C} / \mathrm{N}$ ratios show a marked difference in the rate of decomposition and humification processes of the horizons. Generally, the high $\mathrm{C} / \mathrm{N}$ values at the topsoil indicate recent deposition of organic matter, while the variable values down the profiles may indicate its loss over time and retarded decomposition at some horizons. Organic matter is usually lost in soils over time (Ping et al., 1997). The decline in values of $\mathrm{C} / \mathrm{N}$ ratio at the subsoils of $\mathrm{OGB}_{2}$ and $\mathrm{OGB}_{3}$ indicates advanced stage of humification.

\section{Classification of the Soils}

The soil profiles of the floodplain at Ogbaru are classified according to the USDA Soil Taxanomy and the FAO/IUSS WRB as follows:

Pedon OGB 1 : The soils classify as Entisols at the order level of the USDA Soil Taxonomy because the mineral soils lacked developed soil horizons. At the suborder level, the soils were categorized as Aquents because the soils are seasonally wet for some time. At the great group level, soils were grouped into Fluvaquents due to the important role played by fluvial depositions in its formation. Due to the hydric conditions in all the layers, the soils classified as Typic Fluvaquents at the subgroup level. The soils were correlated with Stagnic Fluvisols in FAO/IUSS WRB (2015).

Pedon OGB 2 : The soils classify as Inceptisols due the presence of an incipient cambic B-horizon. The soils were grouped under the suborder Aquepts because their aquic moisture regime, gleyic properties and ESP $>15 \%$ characteristics do not match other groups in the category. At the great group level, the soils were grouped into Endoaquepts, and further into Fluvaquentic Endoaquepts at the subgroup level following its slope, thickness, presence of transported materials at the surface and irregular decreases in organic carbon. The soils were correlated with Pantofluvic Endostagnic Cambisols in FAO/IUSS WRB (2015).

Pedon OGB3: The profile classifies as Inceptisols due to weak structural development within 30-116 $\mathrm{cm}$ depth. At the suborder level, the soils were grouped under Aquepts. At the great group level, the soil belongs to the Endoaquepts. Due to an irregular decrease in organic-carbon content between depth of $125 \mathrm{~cm}$ with no lithic characteristics and aquic conditions, the soil classify as Fluventic Endoaquepts at subgroup level. The soils correlated with Stagnic Endogleyic Cambisols in FAO/IUSS WRB (2015).

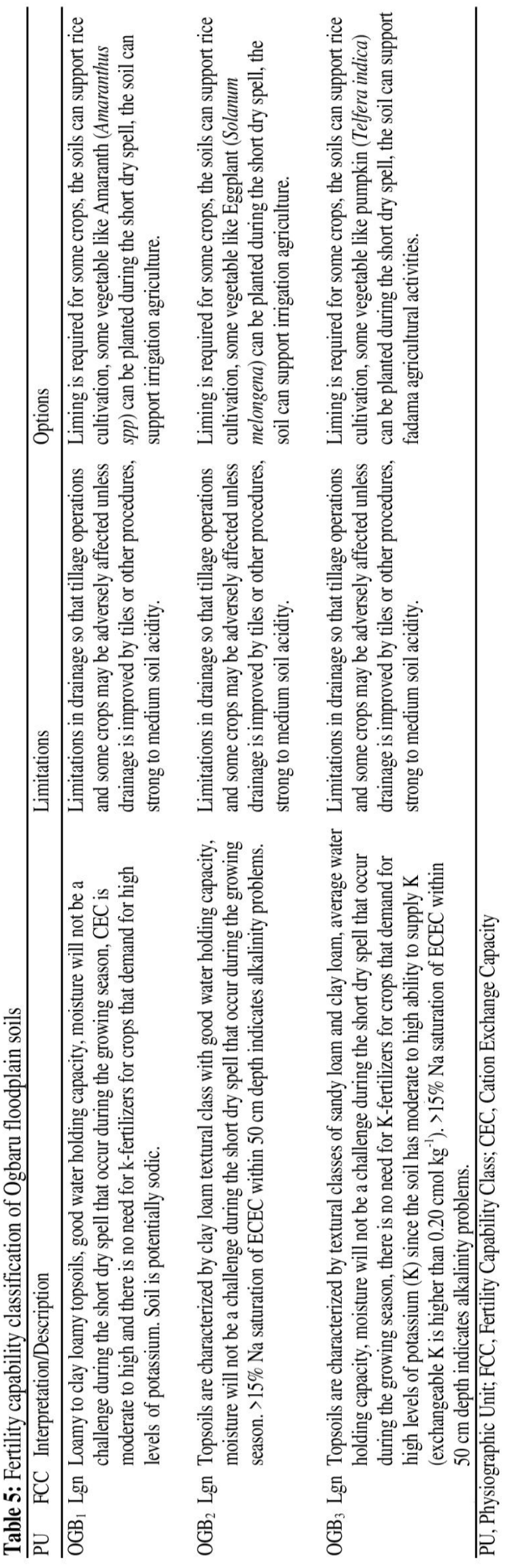


Fertility Classification of Ogbaru Floodplain Soils The fertility classification of Ogbaru floodplain soils are shown in Table 5. The three soil physiographic units $\left(\mathrm{OGB}_{1}, \mathrm{OGB}_{2}\right.$ and $\left.\mathrm{OGB}_{3}\right)$ are classified as Lgh. The soil type L indicates the loamy nature of the soil texture while the modifiers, $g$ and $h$ indicate the hydromophic nature and the strongly acidic state of the soils. The recommendations for the best use of the soils are clearly stated in Table 5 .

\section{CONCLUSIONS}

It is evident that fine-scale topographic landscape variations and the distance from river channel accounts for differences in properties of floodplain soils as well as the use to which the land is put to. More so, the aftermath of major floods results in more pronounced variations associated with fluvial depositions, erosion hazards and aquic conditions. Under these conditions, the studied soils are deep, layered and mottled. Along with the reduced iron content associated with repeated wetting and drying, nature of parent material and organic matter contents contribute to the colour of the soils. At distances closer to the river channel (levees), energy of the deposition media (flood) is greater and becomes weaker down slope. Hence total sand dominated the levee while silts and clay dominated the lower slopes except at the flood basin surfaces where erosion hazard caused by runoff leads to the loss of clay and increased sandiness. Due to frequent depositional disturbances and erosion hazards during floods, the soil development is hampered with closeness to the river channel. Further away from the channel, some layers were compact due to increased clay contents but the increases are mainly related to the nature of deposited parent material rather than pedogenesis. Generally, the soils have low to high base status, organic carbon contents and cation exchange capacity (CEC); reflecting the influence of organic matter and clay content. Soils on the levee slope were most fertile while soils on the levee position were less fertile due to rapid loss of basic cations. On the soil surfaces, higher values of cations reflect flood deposits which were rich in basic cations. There is need for further studies in order to understand the mechanism behind soil salinization in this river floodplain, their mobilization through the soil profile and its impact on crops. More so, the boundary between physiographic zones of the floodplain, as it is with many other floodplains is less understood and will require more detailed study for precision agriculture. Management of the soil requires drainage during cropping season, subsoil liming in order to replace negative charges in the exchange complex with $\mathrm{Ca}^{2+}$ which is low in the studied soils, adequate tillage in order to break clods at the lower slopes. Irrigation agriculture will ensure all round production of vegetables and other crops in the area.

\section{ACKNOWLEDGMENTS}

The paper forms part of the MSc research project of the first author (OFC) at the University of Nigeria Nsukka, Nigeria. The authors wish to gratefully acknowledge the invaluable support and input to the research by members of academic staff of the Department of Soil Science of this University while the first author (OFC) was on the MSc degree programme. Deserving special mention is Dr. S.E. Obalum who, through the corresponding author, provided extra support with useful comments/suggestions on the initial and the final drafts of the paper.

\section{REFERENCES}

Abagyeh S.O.I., Wuese S.T. and Ezenwa M.I.S. (2017). Characterization, classification and management of integrated landscapes in the middle Benue valley of Benue State. Nigerian J. Soil Sci., 27, 267-281

Abreu Jr. C.H., Muraoka T. and Lavorante A.F. (2003). Relationship between acidity and chemical properties of Brazillian soils. Scientia Agricola, 60 (2), 337-343

Ahukaemere C.M., Onweremadu E.U., Ndukwu B.N. and Okoli N.H. (2016). Pedogenesis of two lithologically similar soils under vegetation of contrasting features in Ohaji, South-Eastern Nigeria. Agro-Science, 15 (3), 34-40

Ajiboye G.A., Olaniyan J.O. and Bakare M.O. (2012). Characteristics, classification and management of soils of Kampe-Omi river basin Kogi State. Nigerian J. Soil Science, 22 (2), 211-223

Akamigbo F.O.R. (2001). Soil survey, classification and landuse of wetland soils in Nigeria. Proc. 27th Annual Conf. Soil Sci. Soc. Nigeria, 4 pp.

Akamigbo F.O.R. and Nnaji G.U. (2011). Climate change and Nigerian soils: vulnerability, impact and adaptation. Agro-Science, 10 (1), 80-89

Akamigbo F.O.R., Ezedinma F.O.C., and Igwe C.A. (2001). Properties and classification of some fadama soils of Bauchi State, Nigeria. Proc. 27th Annual Conf. Soil Sci. Soc. Nigeria, pp. 45-51

Asadu, C.L.A. (1989). A Comparative Study and Evaluation of Yam-Zone Soils and the Performance of Six Cultivars of White Yam (D. rotundata) in Southeastern Nigeria. PhD Thesis Submitted to the Department of Soil Science, University of Nigeria, Nsukka, Nigeria, 82-105 pp.

Bohn H.L., McNeal B.L. and O'Connor G.A. (2001). Soil Chemistry ( $3^{\text {rd }}$ ed.), John Wiley \& Sons

Bremner J.M and Mulvaney C.S. (1982). Nitrogen total. In: Page R., Miller A. and Keeney D.R. (Eds.), Methods of Soil Analysis, Part 2 (pp. 595-624) (2 ${ }^{\text {nd }}$ ed.). Madison, WI: Am. Soc. Agron. \& Soil Sci. Soc. Am.

Buri M.M., Ishida F., Kubota D., Masunaga T. and Wakatsuki T. (1999). Soils of flood plains of West Africa: general fertility status. Soil Sci. Plant Nutr., 45 (1), 37-50

Chapman H.D. (1982). Total exchangeable bases. In: Black C.A. (Ed.) Methods of Soil Analysis, Part 2 (902-904). Madison, WI: Am. Soc. Agron. No. 9

Chude V.O., Malgwi W.B., Amapu, I.Y. and Ano A.O. (2011). Manual on Soil Fertility Assessment. Federal Fertilizer Department. FAO and National Programme on Food Security, Abuja, Nigeria, CRC Press, Boca Raton, FL. p. 62 
D’Elia A.H., Liles G.C., Viers J.H. and Smart D.R. (2017). Deep carbon storage potential of buried floodplain soils. Scientific Reports, 7: 8181

Dengiz O. (2010). Morphology, physico-chemical and classification of soils on terraces of the Tigris River in the South-east Anatola region of Turkey. J. Agric. Sci., 16, 205-212

Eleke P.N., Ezeaku P.I. and Okenmuo F.C. (2018). Properties and conservation needs of wetland soils along Kaduna River Northern Guinea Nigeria. J. Sci. Res. Reports, 20 (4), 1-10

Enwezor W.O., Udo E.J., Usoro N.J., et al. (1989). Fertilizer Use and Management Practices for Crops in Nigeria. Fertilizer Procurement and Distribution division, Federal Ministry of Agriculture, Water Resources and Rural Development Lagos, p. 163

Esu I.E. (2010). Soil Characterization, Classification and Survey. Ibadan, HEBN Publ. PLC, Nigeria, pp. 73-99

Fagbami A.A. (1986) Remote sensing options for soil survey in developing countries. ITC Journal, 1, 3-8

FAO (2006). Guidelines for Soil Description, $4^{\text {th }}$ ed. Food and Agriculture Organization (FAO), Rome, p. 109

FAO/IUSS Working Group (2015). World Reference Base for Soil Resources 2014, update 2015 International Soil Classification System for Naming Soils and Creating Legends for Soil Maps. World Soil Resources Reports No. 106. FAO, Rome

Gee G.W. and Bauder J.W. (1986). Particle size analysis. Physical and Mineralogical Methods, Part 1 (pp. 404-408). Madison, WI, USA

Gregory P.J. and Nortcliff S. (Eds.) (2012). Soil Conditions and Plant Growth. Oxford: Wiley/Blackwell

Idoga S. and Azakagu D.E. (2008). Characteristics and management implication of Janta soils, Plateau State for Rainfed rice production, PAT, 4 (2), 53-65

Igwe C.A. Zarei M. and Stahr K. (2006). Clay dispersion of hardsetting Inceptisols in Southeastern Nigeria as influenced by soil components. Communications Soil Sci. Plant Anal., 37 (05-06), 751-766

Jackson M.L. (1958). Soil Chemical Analysis. New Jersey: Prentice-Hall, Englewood Cliffs

Kefas P.K., Ukabiala M.E. and Azuka C.V. (2016). The physical properties and micronutrients status of Mayo-gwoi floodplain in Taraba state, Nigeria. Int. J. Plant Soil Sci., 10 (6), 1-8

Layzell A.L. and Eppes M.C. (2012). Holocene pedogenesis in fluvial deposits of the Conejos river valley Southern Colorado. The Compass: Earth Sci. J. Sigma Gamma Epsilon, 84 (4), 12-18

Lima H.N., Scaefer C.E.R., Mello W.V.J., Gilkes R.J. and Ker J.C. (2002). Pedogenesis and pre-Colombian land use of "Terra Preta Anthrosols" ("indian black earth') of Western Amazonia. Geoderma, 110, 1-17

Markewich H.W., Lynn W.C., Pavich M.J., Johnson R.G. and Meetz J.C. (1988). Analyses of four Inceptisols of Holocene age, East-Central Alabama (Pedologic studies in the eastern United States in relation to geology). U.S. Geological Survey Bulletin, 1589

Mclean E.O. (1982). Soil $\mathrm{pH}$ and lime requirement. In: Page et al. (Eds.), $2^{\text {nd }}$ ed (pp. 199-224). Madison, WI: Agron. 9. SSSA
Medugu I.N. (2006). Achieving sustainable agriculture in Nigeria: a land-use policy perspective. Tokyo Academic, Industry \& Cultural Integration Tour, 1019 December, Shibaura Institute of Technology, Japan

Moustakidis I.V. (2016). Floodplain Phosphorus Distribution in an Agricultural Watershed and Its Role in Contributing to In-Stream Phosphorus Load. $\mathrm{PhD}$ Thesis, University of Iowa. https://doi.org/10.17077/etd.wsn1g88o

Nelson D.W. and Sommers L.E. (1982). Total carbon, organic carbon and organic matter. In: Page R., Miller A. and Keeney D.R. (Eds.), Methods of Soil Analysis (pp. 539-579). Madison WI: Agron. 9, Soil Sc. Soc. Am.

Nigeria Meteorological Agency (2013). NIMET seasonal rain prediction (SRP). Abuja, Nigeria, pp. 1-15

NRCS (2011). Soil quality: indicators: Soil structure and macropores. Soil Quality for Environmental Health. Natural Resources Conservation Service (NRCS), East National Technology Support Center. Retrieved from www.SoilQuality.org. (19/9/2011).

Nwite J.C., Obalum S.E., Igwe C.A. and Wakatsuki T. (2017). Interaction of small-scale supplemental irrigation, sawah preparation intensity and soil amendment type on productivity of lowland sawahrice system. South African J. Plant Soil, 34 (4), 301-310

Nwite J.C., Obalum S.E., Igwe C.A. et al. (2012). Sawah rice system, a technology for sustainable rice production and soil chemical properties improvement in Ebonyi State of Southeastern Nigeria. World J. Agric. Sci., 8 (4), 351-358

Obalum S.E. and Chibuike G.U. (2017). Air-drying effect on soil reaction and phosphorus extractability from upland-lowland tropical soils as related to their colloidal stability. Appl. Ecol. Environ. Res., 15 (1), 525-540

Obalum S.E., Nwite J.C., Oppong J., Igwe C.A. and Wakatsuki T. (2011). Variations in selected soil physical properties with landforms and slope within an inland valley ecosystem in Ashanti Region of Ghana. Soil Water Res., 6 (2), 73-82

Obalum S.E., Nwite J.C., Watanabe Y., Igwe C.A. and Wakatsuki T. (2012). Comparative topsoil characterization of sawah rice fields in selected inland valleys around Bida, north-central Nigeria: physicochemical properties and fertility status. Trop. Agric. Dev., 56 (2), 39-48.

Obalum S.E., Watanabe Y., Igwe C.A. Obi M.E and Wakatsuki T. (2014) Puddling intensity for lateseason sawah systems based on soil hydrophysical conditions and rice performance, Int. Agrophys., 28, 331-340

Ogbodo E.N. (2011). Assessment of some soil fertility characteristics of Abakaliki urban floodplains of South-East Nigeria, for sustainable crop production. World J. Agric. Sci. 7 (4), 489-495

Ogunwale J.A., Olaniyan J.O. and Aduloju M.O. (2002). Morphological, physico-chemical and clay mineralogical properties of soils overlying Basement Complex Rocks in Ilorin East, Nigeria. Moor $J$. Agric. Res., 3 (2), 147-154 
Okeke I.C., Odunga S.S. and Oyebade L.B. (2011). Global change on rural water systems in southwestern Anambra State, Nigeria. Department of Geography, University of Lagos, Akoka, Lagos, Nigeria. Retrieved from www.web.natur.cuni.cz/.../209_session, on 2/3/13

Okenmuo F.C. (2015). Impact Assessment of the 2012 Flooding on Soil Properties and Pedogenesis in the Lower Niger Floodplain at Ogbaru, Anambra State, Nigeria. MSc Dissertation Submitted to the Department of Soil Science, Faculty of Agriculture, University of Nigeria, Nsukka, Nigeria

Okunsami T.A., Rust R.H. and Juo A.S.R. (1987). Properties and classification of five soils on alluvial landforms in central Nigeria. Can. J. Soil Sci., 67, 249-261

Page A.L., Miller R.H. and Keeney D.R. (1982). Methods of Soil Analysis, Part 2 ( $2^{\text {nd }}$ ed.). Madison, WI: Soil Sci. Soc. Am.

Ping C.L., Michaelson J.M., Loya W.M., Cradler R.J. and Malcolm R.J. (1997). Characteristics of soil organic matter by stable isotopes and radiocarbon ages of selected soils in arctic Alaska. In: Drozd J., Gonet S.S., Senesi N. and Webber J. (Eds.), Role of Humic Substances in Ecosystem and in Environmental Protection. Polish Soc. Humic Subst., 475-480, Grunwaldzda, Wroclaw, Poland

Sakar J.P., Landey R.J. Kalbande A.R. and Mandol C. (2001). Characteristics and classification of soils of Kathiawar region Guararat as influenced by topography. Geoderma, 15, 401-411

Sanchez P.A., Couto W. and Boul S.W. (1982). The fertility capability classification system. interpretation, applicability and modification. Geoderma, 27, 283-309
Schiavo J.A., Dias Neto H.A., Pereira G.M., Rosset J.S., Secretti L.M. and Passenda R.C.L. (2012). Characterization and classification of soils in the Taquari river basin- Pantana region, state of Mato Grosso do Sul, Brazil. Revista Prasiliera de Ciercia do Solo, 36 (3), 697-707

Silva Neto L. de F da., Inda A.V, Nascimento P.C.D., Giasson E., Schmitt C. and Curi N. (2015). Characterization and classification of floodplain soils in the Porto Alegre metropolitan region, Rs, Brazil. Cienc. Agrotech., Lavras, 39 (5), 423-434

Soil Survey Staff (2014). Keys to Soil Taxanomy $\left(12^{\text {th }}\right.$ ed.) United States Department of Agriculture and Natural Resources Conservation Service

Stoeckel D.M. and Miller-Goodman M.S. (2001). Seasonal nutrient dynamics of forested floodplain soil influenced by microtopography and depth. Soil Sci. Soc. Am. J. 65, 922-931

Udo B.U., Edem S.O., Udom G.N. and Ndaeyo N.U. (2006). Chemical characteristics of wetland soils in Akwa Ibom State. Nigerian J. Agric. Technol., 13, 112

Ukaegbu E.P. and Akamigbo F.O.R. (2004). Influence of physiography on the properties and use of soils of the Cross River Plain: A case study of a strip of land at Ishiagu, Ebonyi State. Proc. $29^{\text {th }}$ Annual Conf. Soil Sci. Soc. Nigeria

Umeugochukwu O.P. (2009). Morphology, Characterization and Classification of Soils of Api River Floodplain in Opi, Southeastern Nigeria. MSc Dissertation, Submitted to the Department of Soil Science, University of Nigeria, Nsukka, Nigeria 